\title{
Women Education: Women and Teaching Profession in Ghana
}

\author{
Wang Jiajia ${ }^{1} \&$ Portia.V. Samba ${ }^{2}$ \\ ${ }^{1 \& 2}$ School of Teacher Education, Jiangsu University, Zhenjiang, China \\ Correspondence: Portia Samba, Jiangsu University, Zhenjiang, China. \\ Email: portiasamba@qq.com
}

Received: July 12, 2019

Accepted: August 29, 2019

Online Published: September 1, 2019

doi: 10.23918/ijsses.v6i1p72

\begin{abstract}
Feminist theorists raise questions about hypotheses that are still common in the teaching fields that consist mostly of women. Education is a force that allows women to have expanded choices in the approach to capabilities and The World Bank is promoting education for women as it contributes to human capital. The purpose of this paper is to discuss women education, the teaching profession, and feminization of teaching in Ghana. It highlights and analyze why women are concerned about education, aspects of women's education in Ghana, and why women are interested in teaching. Findings indicated that Ghanaian women are into teaching because of numerous reasons but a few of them include, the acceptance in the teaching profession i.e. they feel accepted and there is no discrimination. In addition, there is job security in the profession.
\end{abstract}

Keywords: Women Education, Teaching, Ghana, Feminized

\section{Introduction}

\subsection{Women Education}

Before the Caribbean slave emancipation of 1835, there was no official education for Black slaves. During the pre-emancipation era, education was specifically reserved for White class kids and clergymen (Esnard, 2010). As for the total return to education, family formation influences and restricts both genders ' financial return to education continuous to have a particularly significant impact on the education of women. Studies confirm that almost half of the return to higher education for women who graduated from college between 1945 and 1960 comes in the form of a higher-income spouse (Kim \& Sakamoto, 2017).

The return of the labor market to college education for both males and females has risen considerably. Several studies have shown that females have a greater college salary premium than males. One of the most prominent stylized facts about the gender difference in educational exchange is that, the comparative college price for females is greater than for males (Kim \& Sakamoto, 2017). Gender is not always the disease needed to cause the scales to fall from one's eyes (Pinnick, 2008) because, Special classes for women in the USA have been intended to raise consciousness of the possible impacts of sexual bias on their life. Such an experience can truly increase the level of self-awareness. Through surveys it was claimed that the instructors or counselors of these courses must be feminists themselves (Gerdur, 1988).

The interplay between education, work, marriage and kids dominates women's life. As these variables change and influence each other, both the life cycle and the family change. Marriage and kids used to drive women's jobs and educational decisions. More than $80 \%$ of females worked in 1999, and $14 \%$ of those 
who did not work gave the reason they cared for their home and family (Costello, Wight, \& Stone, n.d.). Women with greater schooling are more likely to work after marriage or return to job after their childcare than females with less schooling. Moreover, females with higher education are more likely to join jobs, such as teaching or civil service, where males and females receive equal pay. In other nations, where less trained females face higher discrimination in terms of wages or where there is a higher distinction in involvement in the labor force, educated females tend to be less discriminated against in terms of wages than females with less education, because higher education offers access to many of the employment. Where equal pay is implemented, the real impact of pay discrimination may be to raise the rate of return to education by raising the gap between educated and less educated females (Woodhall, 1973).

\subsection{Teaching Profession}

Why are young individuals motivated to choose teaching as a profession? The reasons for selecting teaching as a profession have been a study subject over the past decades, and it is likely to be a continuing problem for academics as long as attempts to recruit and retain educators continuous to be made. Many beneficial and negative factors have been observed in the teacher education literature as influencing the choice of young people to follow a teaching career. Teaching is a profession requiring a high level of responsibility and altruism. Consequently, motivating young individuals into the teaching profession appears to be such a difficult job. Furthermore, since education seems to be an occupation that is deemed central to the growth and well-being of a country, there is an understandable concern for the next generation regarding the nation-building mission. (Yu, 2013).

Locating teaching within political discourse shows that teaching articulation, what teaching is, how it is arranged, teaching affinities and prohibitions are in no way natural or given. Policies position teaching in sets of complicated relationships that define what does and counts not only as learning, but also as distinguishing between good and bad or mediocre teaching. This assessment is concerned with the manner in which teaching is provided with a favorable content in policy discourses, i.e., the grounding of a normative order through learning, and the issues this poses for ethical learning based on negativity. Instead of educators, I see teaching as a basis because of the practice involved in it (Carusi, 2017).

Thus, women's inferior position (which can be expressed on a scale of degrees of marginalization or merely of non-use of their capacity) impoverishes the entire pattern of culture and deprives it of the creative capacity of the female population within the framework of the social procedures. Women's position in our societies is a social issue that depends on public policies and organizational procedures (Eliou, 1988). As a key component of higher education settings, Teaching at universities requires the interest of teachers in teaching, impeccable integrity in teaching and learning tasks and professional culture development (Sethy, 2018). Teaching is defined, as a job, by the scope and remit of teaching norms. Teaching at an established college is considered a profession because college professors have a dual status: a moral agent and a coach. A moral agent has a flawless conduct such as honesty, fair-mindedness, unbiased approach, etc. A professor helps learners construct their personality, seeks moral virtues like accountability, bravery, kindness, patience, self-discipline, empathy, respect for others, etc.

Similarly, pre-service educators from some developed countries thought that teaching is a challenging profession and needs expert understanding. Pre-service educators from the United States and Australia 
strongly thought that the teaching profession had a strong social status, but it is low-paid while Germany thought that the teaching profession had a low social status, yet it is well paid. Similarly, Dutch pre-service educators did not extremely value the wage and social status of the teaching profession compared with skills and difficulty (Eren, 2018).

Teaching is also understood as an emotional exercise where educators are constantly exploring their emotions and using them. While findings show that the feelings of teachers are complicated and difficult to evaluate, the emotion of teachers is bound to influence the well-being of teachers, their self-image as educators, their actions, and other dimensions of their lives. The feelings of educators also relate to the burnout unhappiness of educators with work, stress and early departure from work in their careers (Mevarech \& Maskit, 2015). The commitment of teachers to learning is extensively studied throughout the globe due to its significant contribution to a number of educational elements. Studies clarify that teaching engagement influences the desire of student teachers to join the teaching profession. Gender was disclosed as one of the background to teaching dedication. Engagement and favorable attitudes towards the teaching profession among female students were discovered to be greater than among masculine students (Moses, Admiraal, \& Berry, 2016). Additionally, surveys reveal that many female student teachers demonstrate greater intentions after graduation than masculine student teachers to join the teaching profession.

\subsection{Feminism}

On a purely statistical level, a predominantly female occupation is said to be ' feminized' (Bank, 2007). When sociologists and professionals refer to feminization, they refer to labor market trends in which women's involvement in different jobs is growing (Drudy et al., 2005). Similarly, the European Trade Union Education Committee (ETUCE) Working Group used the word "feminization" to "define the phenomenon of females entering the teaching profession on a large scale ..."(Wylie, 2000, p.1).

When we talk about feminism and education, a contradiction instantly confronts us. Education, on the one side, is seen as a needed and significant aspect of social transformation intervention. On the other side, education systems and college curricula are hierarchically structured and deeply conservative: academic institutions are bastions of male supremacy and authority of the ruling class.

Feminism as a social movement in the United States dates back to the mid-19th century, whereas in the late 1960s and early 1970s its so-called second wave evolved. The moment of the second wave with the creation of the first women's study programs academic feminism started to appear in U.S. higher education. Most of its many professionals continue to regard women's studies as the educational arm of the women's movement, and activism remains an essential part of the now well-established academic field (Bystydzienski, 2002).

There is a growing need for a specifically feminist educational approach. It stems from the fact that feminism is a progressive and momentous kind of historical and political movement. This movement is radical in a very broad sense: It not only calls for modifications in women's living circumstances, But, it also calls into question the male-dominant society's strongest assumptions (Brien, 1986). In regards to the conversion of the position of women in the labor market, three financial periods have been recognized: 
the family-based economy, the family wage economy, and the family consumer economy. These financial periods are approximately parallel to historical phases used to examine learning history. The pre-industrial period (the United States colonial period), the early industrial period (the nineteenth century), and the mature industrial era (the twentieth century).

Feminists are almost as unwelcome as divorcees because their unorthodoxy on the location of women in the globe stirs criticism and is likely to be accompanied in other matters by an agitating spirit. Moreover, males do not like feminists, and the majority of administrators are males. Teaching was seen as a revolving door profession by the early twentieth century, and shortages of skilled educators remained a severe issue. For males who remained in teaching, most came to administrative roles and women teachers ' turnover levels were exceptionally high due to sanctions against their marriage and teaching. The history of teaching shows that while women educators were the dominant participants in the teaching profession, patriarchal ideologies as well as financial, political and social forces influenced their involvement (Dee, 1997).

Women encountered "numerous threats" based on their situation of gender, ethnicity and class. Others have observed that race, class and sex interlock oppressive structures that form a matrix of dominance and function simultaneously in a manner that is irreducible to individual characteristics (Hill, 2002). Feminism encourages pedagogy that helps learners examine the unknown and question their own hypotheses (Mahoney, 1996). It highlights values, the significance of subjective understanding, and social change concerns. Black feminism is defined as a critical social theory (Williams \& Evans-winters, 2005) because of its engagement to justice, for its own community and/or for other organizations, a critical social concept is ' critical'. Black feminism is concerned with combating financial, political and social injustice for Black women and other oppressed groups as a critical social theory.

\section{Why Women Education Matters}

As the conferences in Cairo and Beijing affirmed, education is one of the most critical areas of empowerment for females. Education is an area that provides some of the most obvious examples of females suffering from discrimination. There are twice as many girls as boys among kids not attending college, and twice as many females as males are among illiterate adolescents.

The World Forum on Education, (Rubio, 2018) highlights the significance of education for growth. However, education is not inclusive in nations where tradition and religion are deeply rooted, and it excludes primarily girls and women. This is the situation with Ghana, where there is no access to schooling for a big amount of boys and girls from patrilineal families. Offering fundamental schooling to women is one sure way of allowing them to create real decisions about the types of life they want to lead. It is established as a fundamental human right by the Convention on the Rights of the Child and the Convention on the Elimination of All Forms of Discrimination against Women. The World Bank is promoting the education of women because it is an input into human capital. Education is a force in the overall strategy that allows females to have extended decisions. The present consensus in the development economy provides priority to women's schooling as a high-paying investment (Arends-Kuenning \& Amin, 2001). Empirical research demonstrates that education for women reduces fertility, improves schooling for children and improves the health of children. The empirical findings were used by prominent development economists such as Lawrence Summers (former Treasury and World Bank official) and Paul Schultz to 
argue that developing nations should invest strongly in women's education. This argument has proved persuasive, and therefore, the World Bank and other development organizations are offering financing for programs that encourage parents to send girls to college.

For instance, an educated female is probable to marry at later age and have fewer kids. Cross-country studies indicate that an additional year of girls' education decreases fertility rates by $5-10 \%$. In addition, an educated mother's kids are more likely to survive during childbirth. The infant mortality rate of babies whose mothers have received primary education in India, for instance, is half that of kids whose mothers are illiterate. Education generates aspirations for greater living standards, thus reducing the amount of kids in a family desired. Education exposes females to "birth control-friendly, understanding attitudes and procedures" that would allow females to have their required amount of kids. Mcclamroch also indicates that increased labor involvement by decreasing women's reliance on males and kids provides women "alternative sources of social identity and financial support" (Mcclamroch, 1996).

Arends-Kuenning and Amin (2001) further espouse that growth-oriented development economist's advocate investment in women's schooling because it adds to human capital. Human capital contributes to a productive system and improving human capital improves the goods that a society can generate. Increasing the instructional level of a society results in greater rates of economic growth as educated individuals are more productive than uneducated individuals are. For instance, a book published by the World Bank in 1993, The East Asian Miracle, attributed much of the unprecedented growth rates of Southeast Asia from the 1970s to the 1990s to the region's emphasis on education. An educated female will be better paid and more productive at job. Studies from a number of nations indicate that an additional year of education will boost the future income of a woman by around $15 \%$ compared to $11 \%$ for a man. Women with the possibility of a healthier and happier life should be sufficient reason to promote the education of women because there are significant advantages for society as a whole. An educated female has the abilities, knowledge, and confidence to be a better parent, employee, and citizen.

\section{Aspects of Women Dominance in Ghana}

In 2006, the World Economic Forum launched the Global Gender Gap Index as a framework for identifying the magnitude of gender-based disparities and monitoring their progress. The index benchmarks domestic gender gaps in financial, political, educational and health criteria and offers country rankings for efficient regional and earnings comparisons. The rankings are intended to generate higher understanding of the problems presented by gender gaps and the possibilities generated by decreasing them among a worldwide crowd. Economic involvement and possibilities, education, health and survival, and political empowerment are the main elements of the index. Ghana scored 0.6772 in financial involvement and chance, with a ranking of 64th place, according to the Global Gender Gap Report (2014). The nation scored 0.9104 in terms of academic achievement, putting it in 117th place. Ghana scored 0.9669 for health and survival-in 116th place. The nation scored 0.1097 for political empowerment - in 97th place. Overall, the nation scored 0.6661, making it 101th out of 142 nations, showing that Ghana is still lagging behind in relation to women empowerment. (ECOWAS and FAO report, 2018).

The 2010 National Population and Housing Census (Ghana Statistical Service, 2013) shows that the percentage of employed men is slightly greater than that of employed women, with the exception of 
services and sales (31.4\% for women and $10.2 \%$ for men) and basic occupations ( $7.5 \%$ for women and $4.3 \%$ for men). The Ghana Living Standards Survey (GLSS) Six (6) corroborates these results, showing that the percentage of women involved in facilities and sales work (31.3 percent) is more than three times that of men (9.2 percent). The 2010 National Population and Housing Census (PHC) indicates that about 46 percent of employed males job in agriculture, including forestry and fishing, about 12 percent work in wholesale, retail and motor vehicle and motorcycle repair, and about 9 percent work in manufacturing. For women, the proportion was $38 \%$ in agriculture, $25 \%$ in wholesale and retail, $13 \%$ in production and about $9 \%$ in housing and food services. On gender trends in jobs, the 2010 PHC report demonstrates that the percentage of the male population employed fell from $46 \%$ in 1960 to $42 \%$ in 2010, while the percentage of women rose from $30 \%$ in 1960 to $42 \%$ in 2010. Furthermore, the census shows that more than $90 \%$ of those employed were economically active in 2010 , with $95 \%$ for men and $94 \%$ for women. The World Bank Global Findex Report (2011) supports these figures, indicating that:

1. The level of female labor involvement (i.e. percentage of women over 15 years of age) is 67 percent.

2. Females make up the bulk of the informal sector's 92 percent workforce.

3. Females employed in the non-farm industry make up $32 \%$.

4. Female employers make up 4 percent of the total.

\section{Why Most Ghanaian Women Are in Teaching}

United Nations Educational, Scientific and Cultural Organization (UNESCO) data indicates that a significant number of Ghanaian women are in teaching. When you question these women, why they are into teaching? Each of them has their story to tell for pursuing the educational program to become a teacher.

Industrialization is changing the economy by leading men in fresh directions involving company and more stock-market cash trading, railway planning and factory management. According to Hoffman, there were thousands of vacant teaching jobs accessible from the sudden shift in economic opportunity. Because of restricted work choices, the 1800's women were economically susceptible, and education meant they could be independent. She further explained that, the ideology of the late 19th century was, "The masculine teacher was insufficient if the idea of schools were to develop character" 19th century educators took this chance to state that females were the "natural" educators and that in grade schools they should take the place of males. Females were more apt to be educators than males because they were more apt to work with human development and tended to be more benevolent and ready to commit says a Ghanaian female teacher.

The increasing feminization of learning throughout the 19th century was also ascribed to a fresh perspective of kids; kids are seen as nice little innocent creatures not imps of Satan. As in the Puritan culture, the concept that nurturing females are best suited to teaching kids, as well as the reality that females could be paid less. Most school owners in Ghana would prefer to employ females because they could be paid less yet they will not complain.

An increase in immigration merely meant that in the towns there were more kids, which also supported teacher demand. As more and more young girls took seats to be trained as educators in lecture halls, fewer 
and fewer males were considered suitable for the job. In Ghana, teacher-training colleges are made up of more females than males. The Ghanaian male expects to be revered as the family's "head". So if there are occurrences that will make him lose his" dignity "he will definitely look for and alternate just to keep it. Teaching is poorly paid in Ghana and because of that; most women do not even want to marry teachers because they feel that a teacher cannot take care of them as demanded by African culture and this is making the Ghanaian man shy away from teaching leaving the profession for women.

Table 1: Percentage of female teachers in Ghana by teaching level of education

\begin{tabular}{|c|c|c|c|c|c|c|c|}
\hline & 2012 & 2013 & 2014 & 2015 & 2016 & 2017 & 2018 \\
\hline $\begin{array}{l}\text { Percentage } \\
\text { of teachers } \\
\text { in pre- } \\
\text { primary } \\
\text { education } \\
\text { who are } \\
\text { female }(\%)\end{array}$ & $82.62 \%$ & $83.21 \%$ & $82.98 \%$ & $82.65 \%$ & $82.78 \%$ & $82.76 \%$ & $82.72 \%$ \\
\hline $\begin{array}{l}\text { Percentage } \\
\text { of teachers } \\
\text { in primary } \\
\text { education } \\
\text { who are } \\
\text { female }(\%)\end{array}$ & $36.72 \%$ & $37.91 \%$ & $38.28 \%$ & $38.90 \%$ & $39.71 \%$ & $40.88 \%$ & 41.63 \\
\hline $\begin{array}{l}\text { Percentage } \\
\text { of teachers } \\
\text { in lower } \\
\text { secondary } \\
\text { education } \\
\text { who are } \\
\text { female }(\%)\end{array}$ & $25.36 \%$ & $25.34 \%$ & $25.34 \%$ & $25.31 \%$ & $25.64 \%$ & $25.85 \%$ & $28.28 \%$ \\
\hline $\begin{array}{l}\text { Percentage } \\
\text { of teachers } \\
\text { in upper } \\
\text { secondary } \\
\text { education } \\
\text { who are } \\
\text { female }(\%)\end{array}$ & $22.63 \%$ & $21.73 \%$ & $21.98 \%$ & $22.21 \%$ & $22.63 \%$ & $21.91 \%$ & $22.16 \%$ \\
\hline
\end{tabular}




\begin{tabular}{|l|l|l|l|l|l|l|l|}
\hline $\begin{array}{l}\text { Percentage } \\
\text { of teachers } \\
\text { in } \\
\text { secondary } \\
\text { education } \\
\text { who are } \\
\text { female (\%) }\end{array}$ & $24.51 \%$ & $24.35 \%$ & $24.40 \%$ & $24.81 \%$ & $24.81 \%$ & $25.19 \%$ \\
\hline $\begin{array}{l}\text { Percentage } \\
\text { of teachers } \\
\text { in post- } \\
\text { secondary } \\
\text { non-tertiary } \\
\text { education } \\
\text { who are } \\
\text { female (\%) }\end{array}$ & $24.12 \%$ & -- & -- & -- & -- & -- & - \\
\hline $\begin{array}{l}\text { Percentage } \\
\text { of teachers } \\
\text { in tertiary } \\
\text { education } \\
\text { who are } \\
\text { female (\%) }\end{array}$ & $18.19 \%$ & $18.84 \%$ & $19.46 \%$ & $20.58 \%$ & $20.24 \%$ & -- & \\
\hline
\end{tabular}

\section{Source: UNESCO data}

The statistical and individual surveys of females teaching employees at universities tend to lead us to the following findings:

- Women in the educational profession are underrepresented.

- Women are particularly underrepresented in some academic industries, particularly those with an elevated social status, where university careers can be coupled with lucrative external work.

- Women in senior academic administration are even more under-represented.

- Distribution inequality between the different ranks of the university hierarchy exists to such an extent that:

- Women's careers are hindered, disrupted or developed much slower than their masculine peers are.

\section{Discussion}

This paper was guided by three main issues. Concerning the first issue, women education. Women had no education before 1835; family formation actually influenced the education of women. Most of the women that had higher education between 1945 and 1960 were confirmed to be from higher income spouse. Education is one of the major things that dominate in women's life aside marriage and children. Women who are unable to work always give a reason that; they had to care for their home and family. Instances 
whereby women with less education are being discriminated in terms of wages at the workplace, women with education are less discriminated because higher education gives them access to many opportunities.

The second issue of interest to this study geared towards understanding teaching as a profession. Selecting teaching as a profession has always been an issue in the past decades and still is. Teaching career has its positive and negative benefits. One needs to be responsible in other to be a teacher because the career involves molding young individuals to become better people in the society. Majority of the youth of today are not capable of managing a family less to talk of caring for children. So teaching is a way of helping themselves become better parents as well as the person they always wished to be. Women position in society and family at large makes them more suitable as teachers because they are naturally caregivers and it is an essential part of teaching. Teaching is also a challenging profession because you have students from different backgrounds all coming together in a class and is up to the teacher to employ various skills in handling all these students.

Third, this paper talks about feminism. When one hears "feminism", the first thing that comes to mind is women or females. Feminist movement groups serve as voice for the voiceless women and with lots of discriminations out there in the job market between women, teaching tends to be their last resort. Most men do not like the teaching profession for various reasons. Women education is relevant to societal development as Dr. James Emman Kwegyir Aggrey once said, "If you educate a man, you educate an individual but if you educate a woman, you educate a nation". This is very true because women are often home with family especially the children and she will ensure that good morals and habits are inculcated into the children as she was taught which will go a long way to benefit the society and the nation at large.

According to Table 1, the percentage of women teachers in pre- primary education is huge. Children need strong foundation for them to be able to build on the other years of learning in their lives and women are seen as the right people for these positions. The other years of learning which include, primary, lower secondary, upper secondary etc. Also, have a considerable percentage of women working in those levels with their male counterparts. Since men prefer working with grownups than early childhood learners.

In a nutshell, teaching is left for women because socio-economic development has created job opportunities that activate more male workers to go after new jobs, leaving teaching opportunities to women.

\section{Conclusion}

According to a World Bank research, 62 percent of the world's educators are female, and these figures continue to rise annually. Other advanced nations demonstrate comparable patterns; $83 \%$ of educators in France are females, $86 \%$ in Germany, $87 \%$ in Portugal and $87 \%$ in the UK. Due to the marginalization of academic conditions, 'Teacher' has become the occupation of females as most females can only be accepted in diploma programs and there are restricted alternative jobs for females. Furthermore, females by nature like and care for young kids and teaching is the appropriate task for them by working with kids to satisfy that desire. Teaching is the profession that provides females with appropriate employment circumstances because it provides them time to care for their kids and there is a higher advantage from job 
International Journal of Social Sciences \& Educational Studies ISSN 2520-0968 (Online), ISSN 2409-1294 (Print), September 2019, Vol.6, No.1

security. Moreover, I suggest future studies could be conducted in different cultural contexts, with colleges and universities in order to understand more fully the relationship between women and teaching in Ghana.

\section{References}

Arends-Kuenning, M., \& Amin, S. (2001). Women's capabilities and the right to education in Bangladesh. International Journal of Politics, Culture, and Society, 15(1), 125-142.

Bank, B. J., Delamont, S., \& Marshall, C. (2007). Gender and education: An encyclopedia. Greenwood Publishing Group.

Bystydzienski, J. M. (2002). Women and feminism in the association for humanist sociology. The American Sociologist, 33(4), 66-73.

Carusi, F. T. (2017). Why bother teaching? Despairing the ethical through teaching that does not follow. Studies in Philosophy and Education, 36(6), 633-645.

Costello, C., Wight, V., \& Stone, A. (2016). The American Woman, 2003-2004: Daughters of a Revolution: Young Women Today. Springer.

Drudy, S., Martin, M., O'Flynn, J., \& Woods, M. (2005). Men and the classroom: Gender imbalances in teaching. Routledge.

ECOWAS and FAO. (2018). National gender profile of agriculture and rural livelihoods. India.

Eliou, M. (1988). Women in the academic profession: Evolution or stagnation? Higher Education, 17(5), 505-524.

Eren, A., \& Çetin, G. (2019). Pre-service teachers' beliefs about the teaching profession, curriculum orientations, and personal responsibility. Curriculum Perspectives, 39(1), 19-32.

Esnard, T., \& Cobb-Roberts, D. (2018). The Stony Road We Trod: Black Women, Education, and Tenure. In Black Women, Academe, and the Tenure Process in the United States and the Caribbean (pp. 1-46). Springer.

Hill, S. A. (2002). Teaching and doing gender in African American families. Sex Roles, 47(11-12), 493506.

Kim, C., \& Sakamoto, A. (2017). Women's progress for men's gain? Gender-specific changes in the return to education as measured by family standard of living, 1990 to 2009-2011. Demography, 54(5), 1743-1772.

Mahoney, A. R. (1996). Children, families, and feminism: Perspectives on teaching. Early Childhood Education Journal, 23(4), 191-196.

McClamroch, K. (1996). Total fertility rate, women's education, and women's work: What are the relationships? Population and Environment, 18(2), 175-186.

Mevarech, Z. R., \& Maskit, D. (2015). The teaching experience and the emotions it evokes. Social Psychology of Education, 18(2), 241-253.

Moses, I., Admiraal, W. F., \& Berry, A. K. (2016). Gender and gender role differences in studentteachers' commitment to teaching. Social Psychology of Education, 19(3), 475-492.

O'Brien, M. (1986). Feminism and the politics of education. Interchange, 17(2), 91-105.

Oskarsdottir, G. G. (1988). Women-Education-The labour market. International Journal for the Advancement of Counselling, 11(3), 197-207.

Pinnick, C. L. (2008). Introduction: Women, Science Education, and Feminist Theory. Science \& Education, 17(10), 1053-1054.

Rubio, A. (2018). Factors that impact girls' education in Ghana: the role of cultural mind-set. Electronic version published by Vancouver Island University.

Sethy, S. S. (2018). Academic ethics: Teaching profession and teacher professionalism in higher education settings. Journal of Academic Ethics, 16(4), 287-299.

Spencer, D. A. (1986). Contemporary women teachers: Balancing school and home. Longman New York. 
Williams, D. G., \& Evans-Winters, V. (2005). The burden of teaching teachers: Memoirs of race discourse in teacher education. The Urban Review, 37(3), 201-219.

Woodhall, M. (1973). The economic returns to investment in women's education. Higher Education, 2(3), 275-299.

Wylie, C. (2000). Trends in the Feminization of the teaching profession in OECD Countries 1980-1995. ILO Sectoral Activities Working Paper, Macrh.

Yüce, K., Şahin, E. Y., Koçer, Ö., \& Kana, F. (2013). Motivations for choosing teaching as a career: A perspective of pre-service teachers from a Turkish context. Asia Pacific Education Review, 14(3), 295-306. 